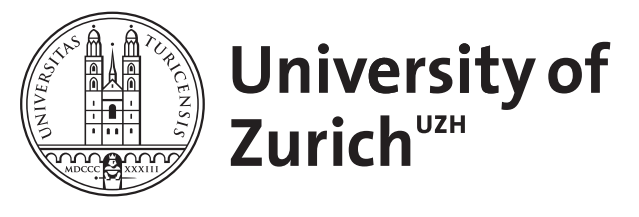

\title{
An Eocene paleodoline in the Morcles Nappe of Anzeindaz (Canton of Vaud, Switzerland)
}

\author{
Linder, Pascal
}

\begin{abstract}
In the helvetic Morcles Nappe of Anzeindaz (Canton of Vaud, Switzerland), Eocene sediments document the successive bypassing of the forebulge and foreland basin of the Alpine orogeny. Cretaceous sediments are cut off by the major erosive unconformity of the so-called "siderolithic" emersion phase. This persistent phase of continental exposure and erosion caused by the presence of the forebulge during the Early to Middle Eocene removed the older sediment record down to the relatively resistant "MidCretaceous" sediments. For the area under consideration, the continental erosion resulted in a peneplain which is perforated at two points by large paleodolines. The study of the sedimentary filling and fossil content of the better preserved one of these paleodolines allows for a reconstruction of the gradual transgression of the foreland basin over the study area. The origin of the paleodoline is interpreted as resulting from a combination of Eocene synorogenic tectonics, providing faults, and the subsequent attack of continental erosion alongside such weak zones
\end{abstract}

DOI: https://doi.org/10.1007/s00015-004-1142-5

Posted at the Zurich Open Repository and Archive, University of Zurich

ZORA URL: https://doi.org/10.5167/uzh-156106

Journal Article

Published Version

Originally published at:

Linder, Pascal (2005). An Eocene paleodoline in the Morcles Nappe of Anzeindaz (Canton of Vaud, Switzerland). Eclogae Geologicae Helveticae, 98(1):51-61.

DOI: https://doi.org/10.1007/s00015-004-1142-5 


\title{
An Eocene paleodoline in the Morcles Nappe of Anzeindaz (Canton of Vaud, Switzerland)
}

\author{
PASCAL LINDER
}

Key words: Helvetic Realm, Morcles Nappe, Eocene, Siderolithic, Sanetsch Formation, Paleodoline

\begin{abstract}
In the helvetic Morcles Nappe of Anzeindaz (Canton of Vaud, Switzerland), Eocene sediments document the successive bypassing of the forebulge and foreland basin of the Alpine orogeny. Cretaceous sediments are cut off by the major erosive unconformity of the so-called "siderolithic" emersion phase. This persistent phase of continental exposure and erosion caused by the presence of the forebulge during the Early to Middle Eocene removed the older sediment record down to the relatively resistant "Mid-Cretaceous" sediments. For the area under consideration, the continental erosion resulted in a peneplain which is perforated at two points by large paleodolines. The study of the sedimentary filling and fossil content of the better preserved one of these paleodolines allows for a reconstruction of the gradual transgression of the foreland basin over the study area. The origin of the paleodoline is interpreted as resulting from a combination of Eocene synorogenic tectonics, providing faults, and the subsequent attack of continental erosion alongside such weak zones.
\end{abstract}

\section{ZUSAMMENFASSUNG}

Eozäne Sedimente in der helvetischen Morcles-Decke von Anzeindaz (Kanton Waadt, Schweiz) dokumentieren die Wanderung der "Forebulge" und des Vorlandbeckens der entstehenden Alpen. Über kreidezeitlichen Sedimenten folgt die sehr bedeutende erosive Diskordanz der "siderolithischen" Emersionsphase. Diese langanhaltende, durch die Anwesenheit der "Forebulge" bedingte Phase kontinentaler Erosion während des frühen bis mittleren Eozäns beseitigte die älteren Sedimente bis hinunter zu den relativ verwitterungsresistenten Sedimenten der "Mittelkreide". Diese Erosionsphase bildete im Untersuchungsgebiet eine "Peneplain" aus, welche allerdings an zwei Stellen von zwei grossen Paläodolinen durchbrochen wird. Das Studium der Sedimentfüllung und des Fossilinhalts der besser erhaltenen dieser beiden Paläodolinen erlaubt eine Rekonstruktion der allmählichen Transgression des Vorlandbeckens über das Untersuchungsgebiet. Die Entstehung dieser Paläodoline wird gedeutet als eine Kombination der eozänen synorogenen Tektonik, welche zu Verwerfungen führte, und der kontinentalen Erosion, welche entlang so gebildeter Schwächezonen angriff.

\section{Introduction}

\section{A) Topic}

In the Early to Middle Eocene, the bypassing of the forebulge and foreland basin of the alpine orogeny through the southern European continental shelf led to the emersion and extensive continental erosion of ancient seafloors, followed by a renewed submersion (Crampton \& Allen 1995, Sinclair et al. 1991). Thus, the Eocene erosive unconformity is a major stratigraphic feature that can be observed over large regions throughout the Helvetic Alps, the Jura Mountains and the Swiss Molasse Basin (Burkhard \& Sommaruga 1998). In the Helvetic Alps, the region of Anzeindaz (see next paragraph) is particularly suitable to study the effects of long lasting continental erosion. Here, a paleodoline has been discovered nearly a century ago (Lugeon 1919). The topic of this article is to describe this structure and its sedimentary filling, a textbook example of a paleodoline, for the first time. Also, its origin shall be discussed.

\section{B) Geographical and geological setting}

The Alp of Anzeindaz lies in the so-called Chablais region of the Swiss Alps and is situated south of the Diablerets Mountains near the border between the cantons of Vaud and Valais. The structure described herein is situated at the mountain range of La Corde (coordinates 578.050/125.375, see Figure 1). A structure similar in form and size is also preserved at the nearby Col des Essets pass (coordinates 578.700/125.075). This structure is less well preserved; therefore, only the first-mentioned structure shall be described here. 


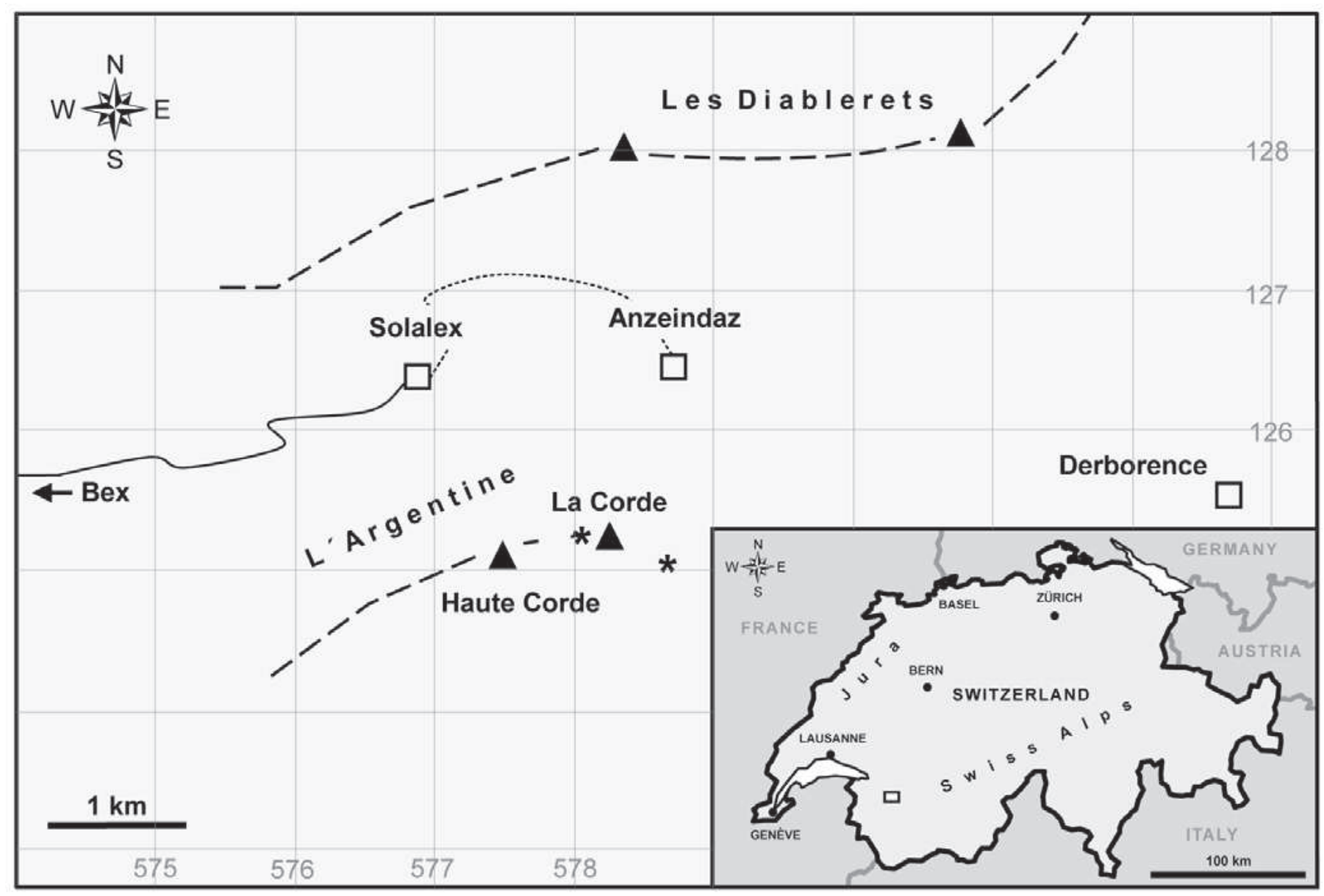

Fig. 1. Geographical situation of the Anzeindaz region. The asterisks mark the paleodolines of La Corde (west) and Col des Essets (east). Squares indicate hamlets, solid and dotted lines mark roads and paths, dashed lines trace mountain ranges, triangles mark individual peaks. Fine lines mark the kilometric topographic grid of Switzerland.

In the Anzeindaz region, the folded frontal zone of the helvetic Morcles Nappe crops out. Its sediments document the evolution of the southern European continental margin during the Mesozoic and parts of the Paleogene: They contain Jurassic and Cretaceous carbonate platform successions; the uppermost of the preserved Cretaceous formations (the Early Cretaceous Schrattenkalk Formation, the "Mid-Cretaceous" Garschella Formation and the Late Cretaceous Seewen Formation) are cut off by the Eocene erosive unconformity. Overlying this unconformity are Eocene and Oligocene transgressive sediments, peaking in Flysch deposits. In the context of this article, the oldest sediments filling the paleodoline are of special interest. They consist of so-called "siderolithic" sedimentary relics related to the Eocene erosion, basal conglomerates and transgressive sediments of the Sanetsch Formation.

\section{C) History}

In 1854, Renevier was the first to visit the site of La Corde and to recognize its Eocene sediments. However, he did not notice the special character of the erosive unconformity in this place. Lugeon (1919) first recognized the structure at La Corde as a paleodoline (see also Lugeon 1940). The sedimentary filling of this paleodoline has since been mentioned by several other authors (e.g. Badoux 1973, Badoux et al. 1990, Masson 1980, Masson et al. 1980) but neither of them described the structure in three-dimensions. The Eocene sediments of the Morcles Nappe were described by Rykken (1968), amongst others. The Eocene Sanetsch Formation, which includes most of the sedimentary deposits infilling the structure, was formally described only recently by Menkveld-Gfeller $(1993,1994)$, based on the work of Herb (e.g. Herb 1988).

\section{Description of the paleodoline and its sedimentary filling}

\section{A) Eocene erosive unconformity}

In the Anzeindaz region, the Eocene erosive unconformity cuts off the relatively erosion-resistant glauconitic and phosphoritic sediments of the Garschella Formation; Scarce relics 


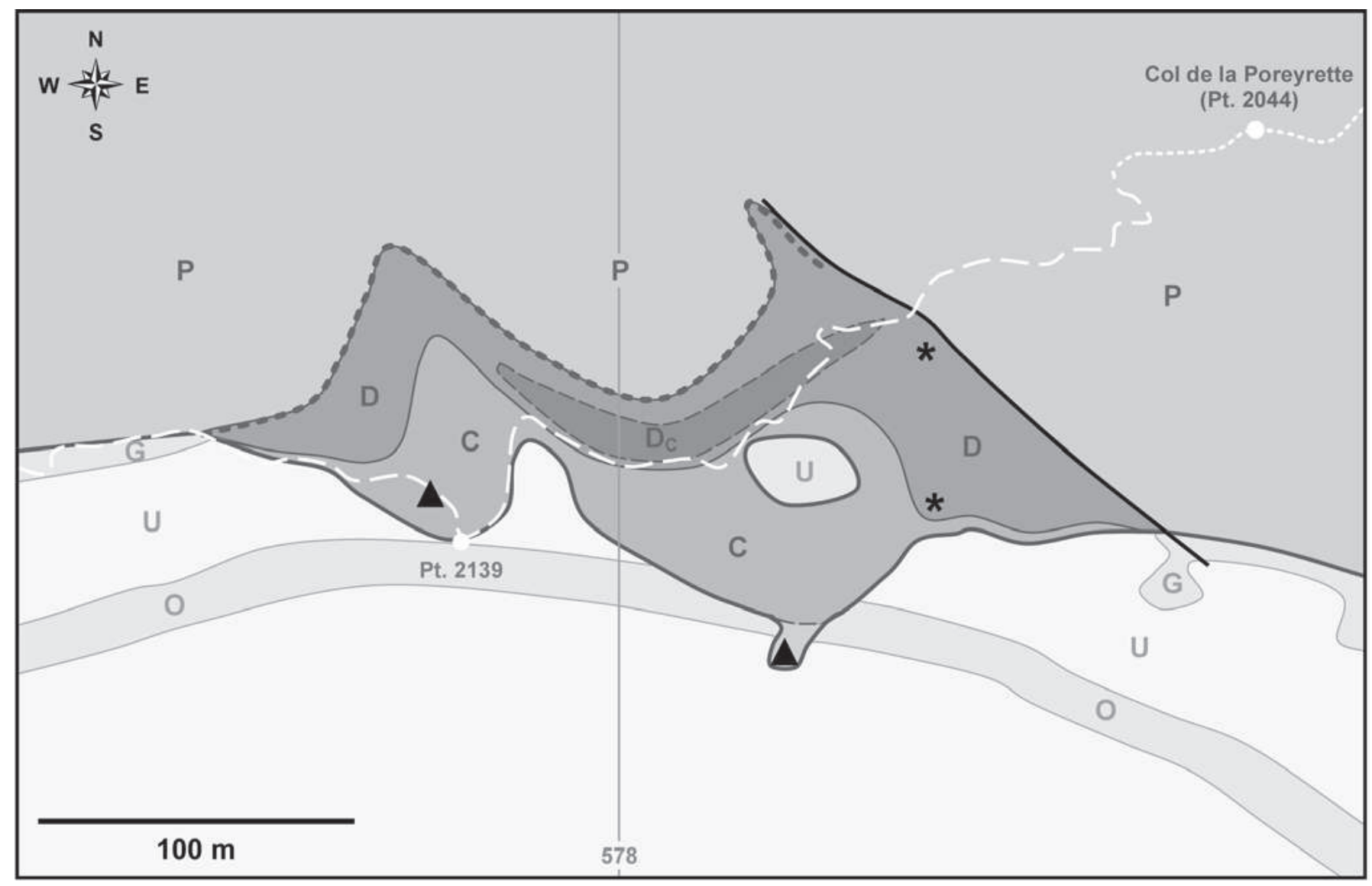

Fig. 2. Map of the paleodoline of La Corde, drawn after aerial photography. Light grey colours: Cretaceous substratum of the structure; Lower Orbitolina Member (O), Upper Schrattenkalk Member (U), Garschella Formation (G). Heavy grey line: eocene erosive unconformity, triangles: siderolithic remnants. The sediments of the Sanetsch formation that are filling the paleodoline are given in darker colours: basal conglomerate (C), Diablerets Member (D), "Cerithium Beds" of the Diablerets Member $\left(\mathrm{D}_{\mathrm{C}}\right)$. The asterisks mark the oyster (north) and coral (south) reefs. The Tsanfleuron Member forming the lid of the paleodoline is traced by the heavy dotted line. The cover of the structure is formed by the Pierredar Member $(\mathrm{P})$. Note the fault cutting off the structure at its northeastern rim (heavy black line). White lines mark the path from Anzeindaz to the Haute Corde peak.

of overlying Seewen Formation limestone are preserved. Thus, the erosive unconformity marks a peneplain (Masson 1980), a paleosurface with a very gentle profile, which is pierced only by the before-mentioned paleodolines. At these points, the Eocene erosion removed the Garschella Formation and parts of the underlying Schrattenkalk Formation limestones (see figure 6).

This unconformity and its siderolithic relics (see paragraph 2 C) are difficult to date since guide-fossils (e.g. mammal teeth) are rare. In fact, no such fossils could be found in the Anzeindaz region. However, in the Authochtone of the Chablais region a single rodent tooth was found (Weidmann 1984) indicating a probably Bartonian age. After a review of existing studies, Herb (1988) and Menkveld-Gfeller (1993) concluded that the Eocene erosive phase took place in the Mid-Eocene (Lutetian and Bartonian). This corresponds to a duration of continental exposure of about 12 my (Gradstein et al. 2004).

\section{B) The paleodoline: geometry and size}

At the notch between the peaks of La Corde and Haute Corde, the sediments of the Garschella Formation have been completely eroded resulting in a bowl-like structure that measures some 300 meters in diameter (see Figures 2, 3 and 6). Due to the outcrop situation, only the northern half of the suspected original structure is still preserved, whereas the southern part has been totally removed by the Quaternary erosion. This allows for a study of a complete vertical section of the structure since it seems to be cut exactly at its deepest point. At this point, the structure reaches its maximum depth of 23 meters with its bottom breaching the Lower Orbitolina Beds of the Schrattenkalk Formation. The northeastern end of the structure is cut off by an alpine normal fault (for discussion see $3 \mathrm{~A}$, last paragraph). This cut-off and the situation of the Quaternary erosional surface lead to a somewhat irregular outcrop situation but the original form of the structure must have been quite regular. 


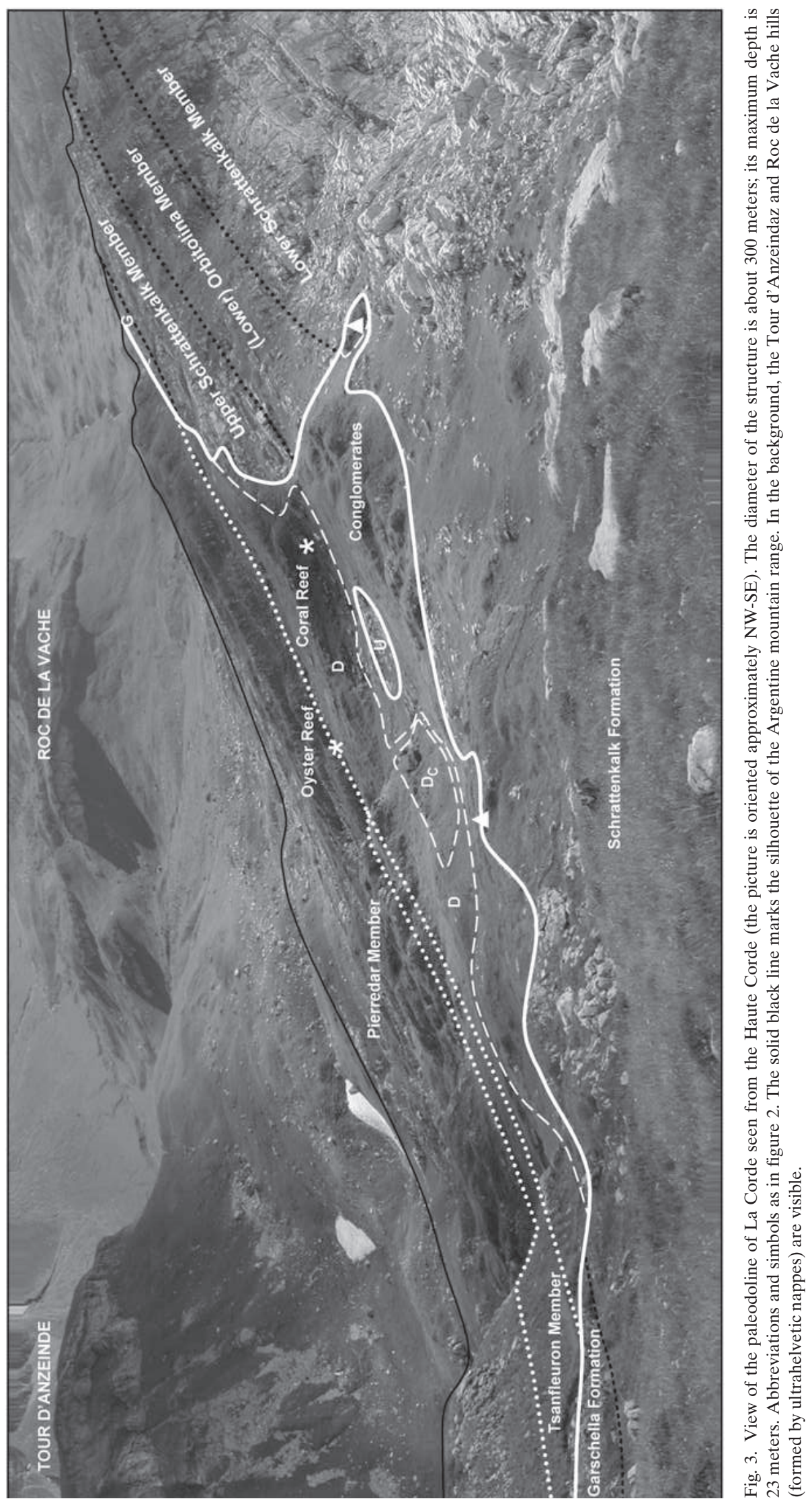




\section{C) Siderolithic sedimentary relics}

The historic term "siderolithic" has been used in context with the often iron-rich (=ferralitic, hence the name) sedimentary relics associated with the Eocene erosive unconformity. However, the term was never formally defined and therefore often used in a very broad, vague and sometimes contradicting manner. Following Wieland (1976) one could define siderolithic sedimentary relics as comprising all autochthonously reworked sediments, paleosols, restites and resediments formed during the warm and humid, subtropic phase of Eocene continental erosion. In this sense, siderolithic relics are clearly differentiated from ordinary continental sediments. It is clear from this definition that siderolithic sediments sensu stricto are very rare, but it is equally evident that a depression such as the paleodoline at La Corde is a good place to preserve such relics, and in fact a variety of siderolithic formations can be found here:

At the deepest point of the structure, four meters of grainby-grain eroded, transported and resedimented sediments of the Garschella Formation can be observed. Sediments reworked in such a kind are common siderolithic features and on first sight easily mistakable for their original sedimentary counterparts (Masson, pers. comm.).

A closer look reveals the redepositional character of these sediments: Firstly, the position of the deposits at the deepest point of the structure, at the stratigraphic level of the Lower Orbitolina Beds is very unusual. Secondly, the sediment consists of a mixture of components from the different lithologies of the Garschella Formation; fine-grained glauconite, sometimes coarse quartz grains and small phosphorite lithoclasts. Furthermore, there are millimetric, chamositic(?) pisoids which represent probably vadose continental formations from the Eocene emersion phase. Finally, and in contrast to the almost structure-less Garschella Formation, the reworked sediments show in some places centimetric irregular beddings, in others millimetric laminations with extension structures (see Figures $4 \mathrm{a}$ and $\mathrm{b}$ ). Judging from these observations, this deposit is interpreted as the sink hole of the structure.

At the western end of the paleodoline, where its filling overlaps the erosional cut-off of the Garschella Formation, iron oxyhydroxide pisoids similar to those in the bottom of the structure are observed in the corroded surface of the Garschella Formation (see Figure $4 \mathrm{c}$ ).

In different places, the erosive surface of the Schrattenkalk limestone at the bottom of the paleodoline shows karstic structures. The karstic infiltrations are filled with reddish, fine- grained clastic sediments that contain some centimetric rustyeroding nodules. Sometimes the infiltrations are so dense that the surface is reduced to an in situ formed, form-fitting pseudo-conglomeratic fabric.

\section{D) Basal conglomerate}

At the bottom of the paleodoline, a conglomerate bed has been deposited. These conglomerates are informally known as "Roc Champion Conglomerat" (Lugeon \& Argand 1937, Rykken 1968, Herb 1988). This bed wedges out near the rim and reaches its maximum thickness of six to nine meters at the deepest point of the structure. This basal transgressive conglomerate is mediating between the continental siderolithic relics and the marginal marine Diablerets Member: It consists of local pebbles of siderolithic origin, mainly of Schrattenkalk Limestone, as well as of Seewen Limestone and Garschella Formation sediments (Fig. 4d). Some rare pebbles are covered by Microcodium carpets (Masson 1980; see also Fig. 4e). The partially siderolithic-derived matrix consists of a ferrous sandstone with abundant Microcodium prisms, some centimetric, rusty-eroding nodules and few oysters. These oysters, which are more abundant in the upper part, are documenting wave-induced reworking of the upper part of the conglomerate during the Priabonian onset of transgression. Indeed, Badoux (1973) mentions Nummulites striatus (BRUGUIÈRE, 1792) from the matrix, indicating a Priabonian age of deposition (or of last reworking, respectively). With the age given by Menkveld-Gfeller (1993) for the Diablerets Member of the Sanetsch Formation, the transgression age can be restricted to the early Priabonian. This is in good accordance with the Bartonian age for the original conglomerate formation proposed by Herb (1988).

In the central part of the structure, the amount of pebbles diminishes in the topmost half meter, giving way to a pebbly sandstone. Here, oysters (Ostrea sp.), sometimes with Cliona sponge borings, and Lithophaga borings in the pebbles become frequent (see Figure $4 \mathrm{f}$ ). At one point near the northeastern rim, a small oyster reef is observed. It is overgrown onto the surface of the Schrattenkalk Limestone, is 60 centimeters high and has a diameter of 30 meters. Here, the sediment consists almost entirely of oysters (see Figure $4 \mathrm{~g}$ ).

Until now (Menkveld-Gfeller 1993, 1994) these conglomerates lack a formal attribution but Dr. Menkveld-Gfeller (pers. comm.) agrees that the "Roc Champion Beds" (sensu Rykken 1968) should be assigned entirely to the Diablerets Member of the Sanetsch Formation.

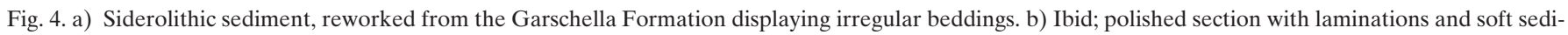

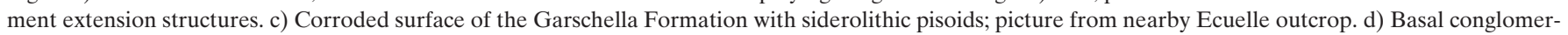
ate with pebbles from different lithologies. e) Microcodium carpets and prisms in a conglomerate made of Seewen Limestone pebbles; Ecuelle outcrop. f) Pebble with lithophaga borings.

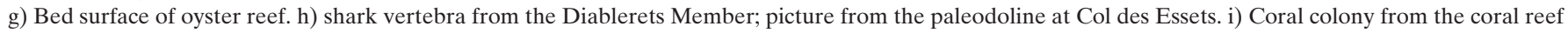
inside the Diablerets Member. j) Typical marly facies of the "Cerithium Beds" (Diablerets Member). k) Bed surface of the Tsanfleuron Member with sea urchin debris. 1) Bed surface of the Pierredar Member ("Nummulithic Limestone") with red algae (Lithothamnium). Abbreviations as in figure 2; S stands for Siderolithic. 


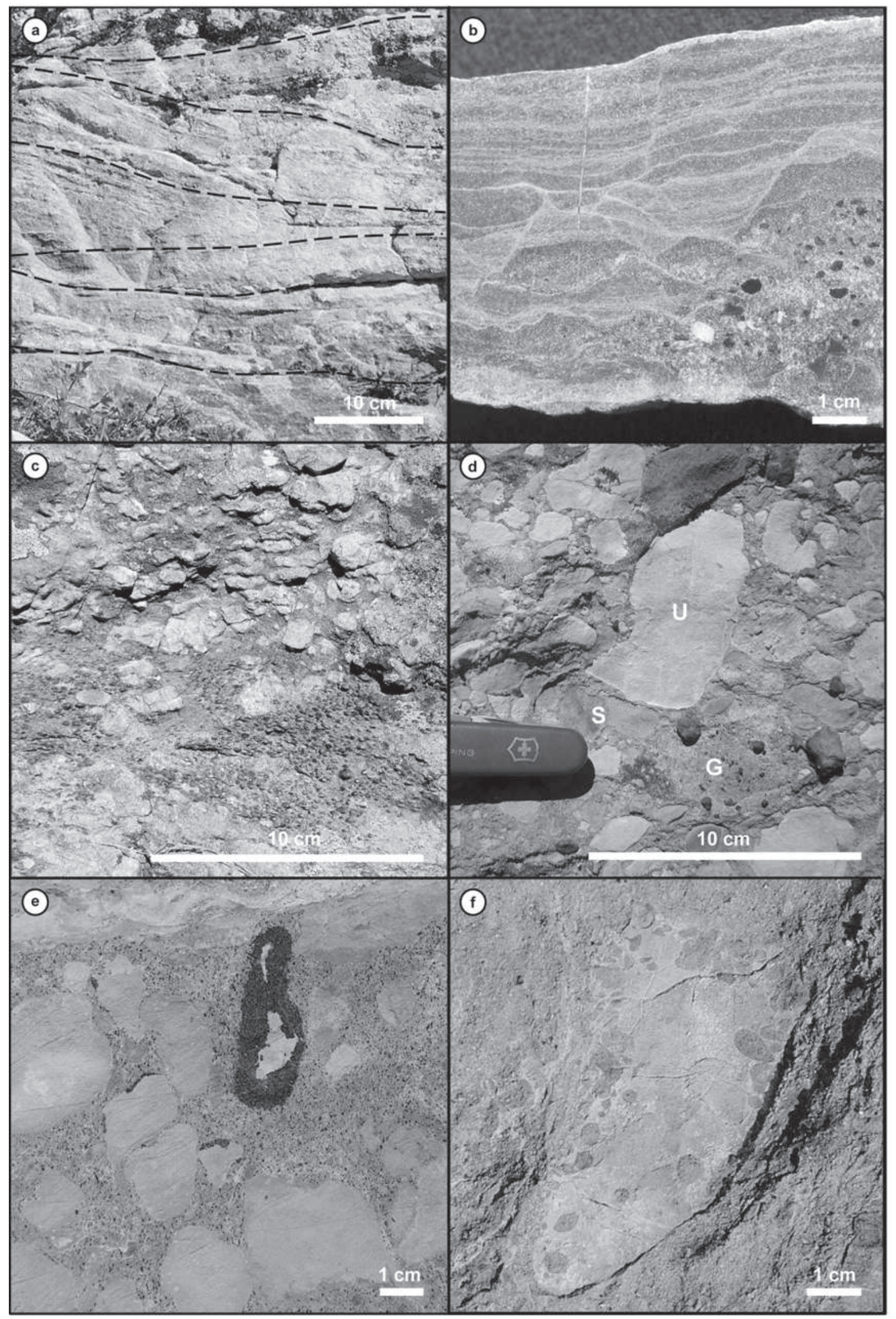




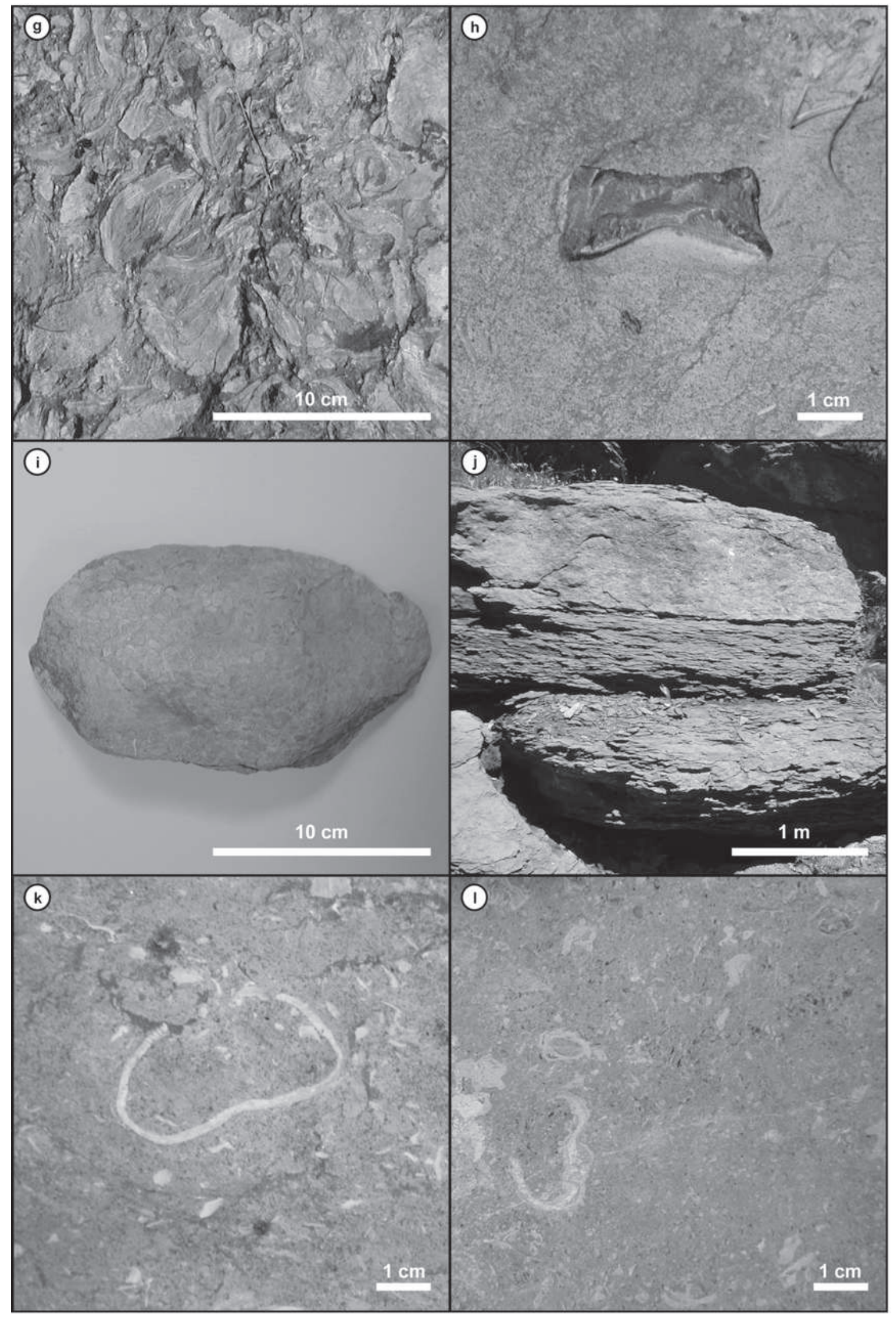




\section{E) Diablerets Member}

On top of the conglomerates, light brown, sandy limestones with abundant centimetric lithoclasts are observed. They wedge out a little bit further to the rim than the conglomerates and measure up to nine meters near the center of the structure. Alveolinid and nummulitid foraminifera, oysters, mussels and gastropods are abundant. Lugeon (1919) mentions Nummulites striatus (BRUGUIÈRE, 1792) from its base. Weidmann et al. (1991) mention tortoise bones as well as fish and shark teeth: Labrus sp., Phyllodus sp., Striatolamia macrota (AGASSIZ, 1843), Carcharias hopei (AgAssiz, 1843).

Halfway to the middle of the structure, a small coral reef is observed. It is overgrown onto the basal conglomerate, measures three meters in height and has a diameter of 20 meters at the base. The corals are mostly branched colonies of Caulastrea, Cyathoseris, Cladocora and Porites (see Figure 4 i).

Near the center of the paleodoline, a three meter thick, lense-shaped body of dark brown, fossil-rich, sandy marls is embedded in the lower part of the sandy limestones without visible unconformity. It contains large quantities of Natica (Ampullina) vapincana D'ORBIGNY and other gastropods, oysters, other bivalves (some of which still display their original colour patterns), coal and bioturbations. Renevier (1890) gave a list of about 30 species from this site which was revised by Boussac (1912, p. 306 ff.). Although they represent a facies of the Diablerets Member (Sanetsch Formation; MenkveldGfeller 1993, 1994) rather than an independent lithostratigraphic unit (Renevier 1854, 1890, Boussac 1912), these sediments are historically known as "Cerithium, Viviparium or Natica Beds" (ibid. and Lugeon \& Argand 1937; see Fig. 4j). In contrast to the light-brown facies of the Diablerets Member, which documents shallow but normal marine conditions, the "Cerithium Beds" document a decisively restricted, probably brackish facies (Badoux 1973) comparable to modern mangrove swamps (Masson 1980).

The age given by Menkveld-Gfeller $(1993,1994)$ for the Diablerets Member is Early Priabonian. This is in accordance with the before-mentioned Nummulites striatus (BRUGUIÈRE, 1792). However, based on the above mentioned fish and shark teeth, Weidmann et al. (1991) rather suggest an Early to Middle Eocene age, but this is in disagreement to the other age estimates mentioned here.

\section{F) Tsanfleuron Member}

The lid of the sedimentary filling of the paleodoline is formed by up to three meters of light brown, sandy limestones (Fig. $4 \mathrm{k}$ ) and a small bed of sandstone with centimetric gravel at the top. It contains alveolinid and nummulinid foraminifera, irregular sea urchins, red algae (Lithothamnium) and Microcodium prisms. The sandstone bed at the top is rich in bivalves, including oysters. The surface of the Tsanfleuron Member (Sanetsch Formation; Menkveld-Gfeller 1993, 1994) is approximately concordant to the bedding of the Cretaceous substratum. In one thin section, Nummulites fabianii (PreVER in FABIANI, 1905 ) could be observed; they indicate a Priabonian age (Linder 2002). This is in accordance with Menkveld-Gfeller (1993), who gives a Middle to Late Priabonian age for the Tsanfleuron Member.

\section{G) Pierredar Member}

The Pierredar Member of the Sanetsch Formation (MenkveldGfeller 1993, 1994) is an approximate equivalent to the historically known "Nummulithic Limestone". It consists of about 100 meters of grey limestones with abundant nummulitid and other foraminifera, red algae (Lithothamnium; Fig. 4l) occasionally preserved with original coloration (Badoux 1973), sea urchins, bivalves, gastropods, corals and bryozoans. The bottom is brownish with reworked sand, centimetric lithoclasts and Microcodium prisms. In contrast to the other members of the Sanetsch Formation, the Pierredar Member has been deposited consistently throughout the Anzeindaz region since it forms the cover of the Eocene erosional surface. MenkveldGfeller (1993) gives a Middle to Late Priabonian age for the Pierredar Member.

\section{Discussion and Interpretation}

\section{A) Origin}

Earlier researchers (Lugeon 1919, Masson 1980, Masson et al. 1980) have interpreted this structure as a karstic feature, a paleodoline. As this structure is eroded deeply into the Schrattenkalk Limestone, the term paleodoline is of course correct; judging from its size it is undoubtfully a compound doline (uvala). However, the denomination as paleodoline is slightly misleading because it also suggests a (purely) karstic origin for this structure. Though, it is important to state that the origin of this structure is not exclusively erosional. This can be understood by two facts:

Firstly, it is very unusual that in most of the Anzeindaz region the Eocene erosional surface forms an almost perfect peneplain (Masson 1980), which is pierced only at two neighbouring places by these huge structures. In the rest of the region, the paleosurface has a gentle profile of only a few meters with very gentle slopes. This seems to be a contradiction in itself. Secondly, the sediments of the Garschella Formation, although never exceeding a thickness of fifteen meters in the Anzeindaz region, are remarkably competent and largely impervious to water. The mere existence of the above-mentioned peneplain shows that there are no reasons to believe that these sediments were less competent or impervious during Eocene times. Hence, they must have formed an effective barrier against the Eocene erosion, causing it to get stuck. The few small relics of late Cretaceous Seewen Limestone on top of the Garschella Formation that can be found in the region prove, that the Eocene erosion could not have reached the Garschella Formation long before it gave way to the subsequent trans- 


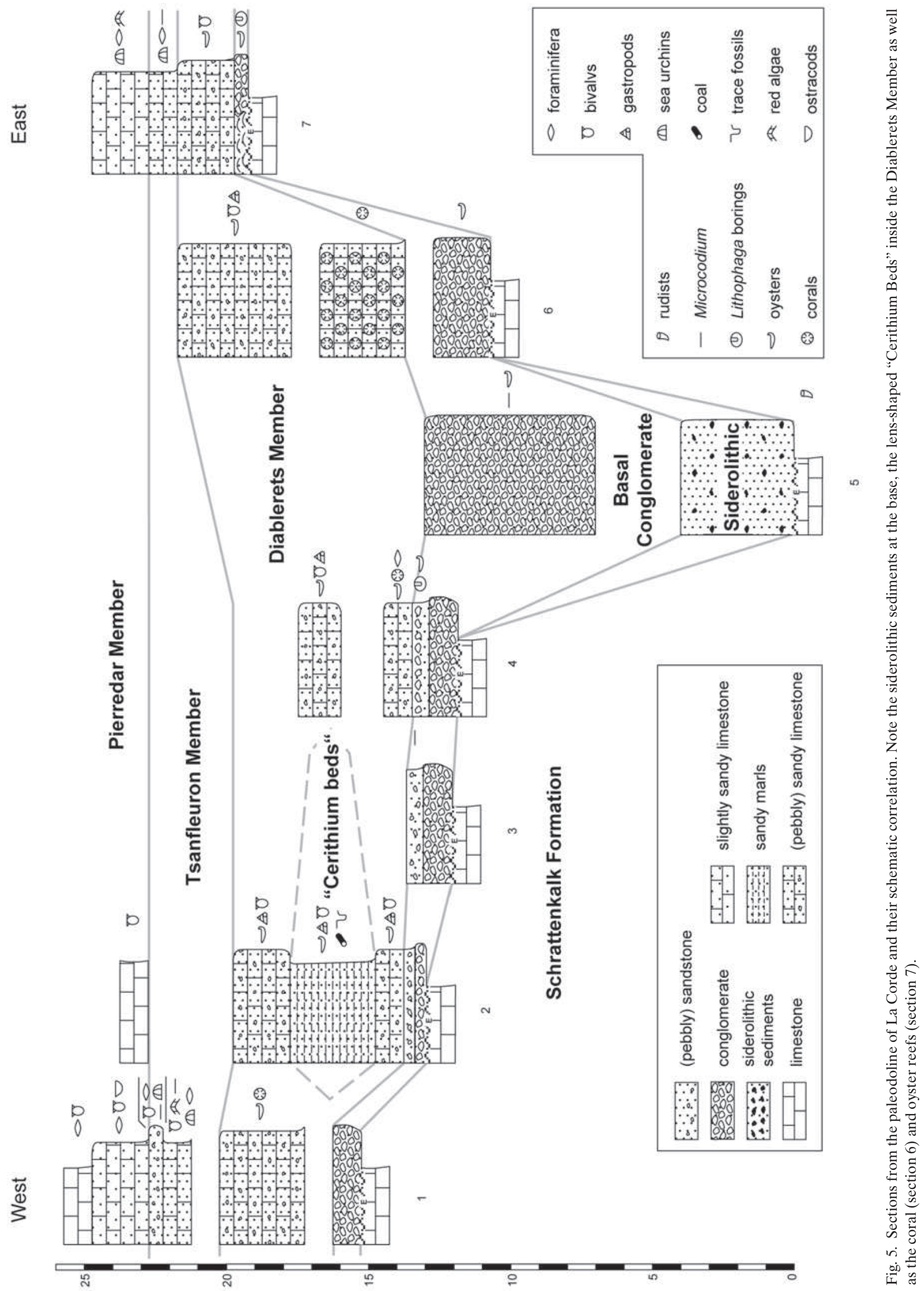




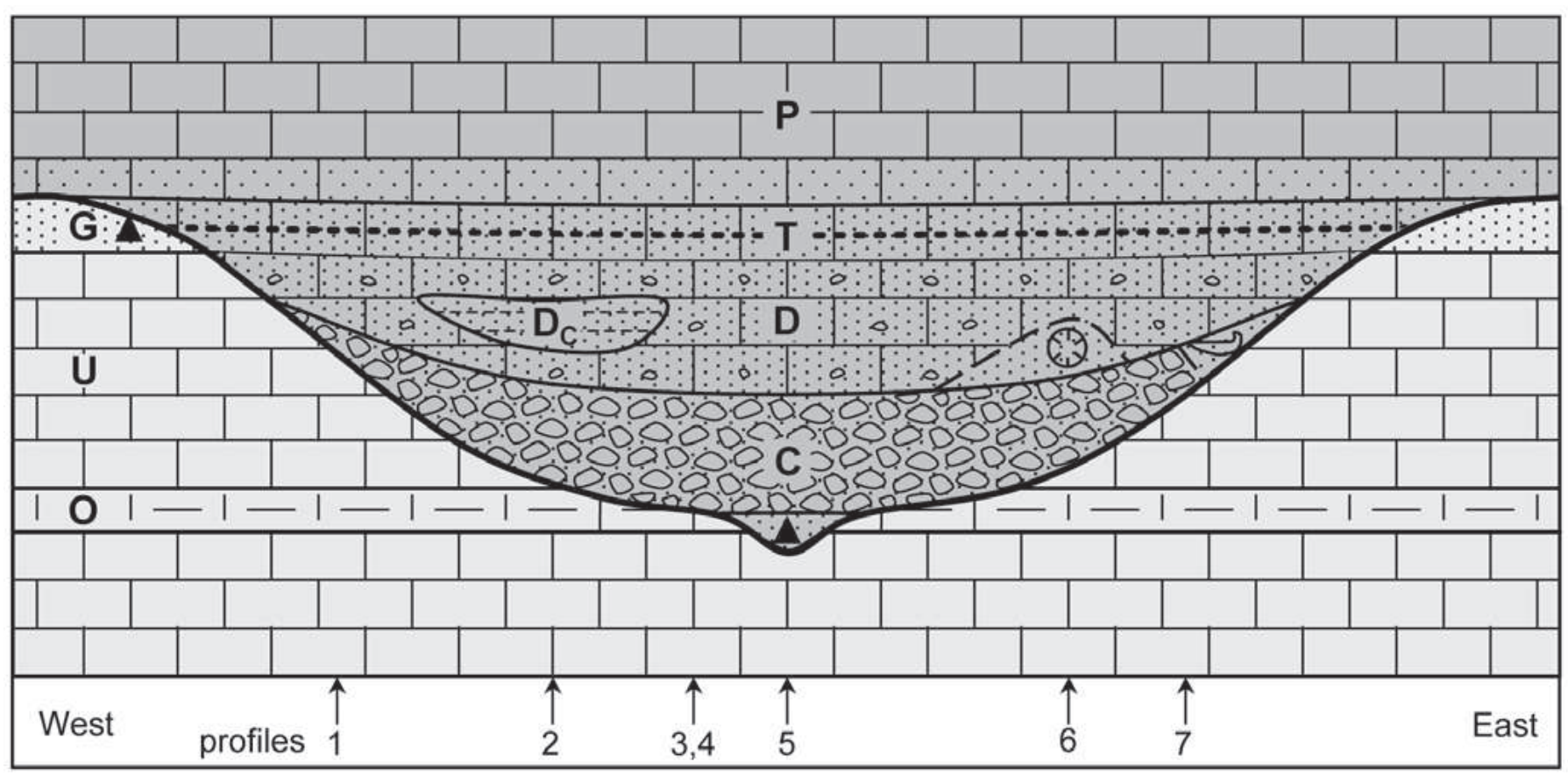

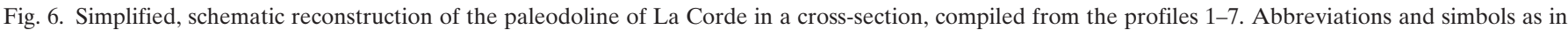
figures 2 and 5. Note the oyster and coral reefs and the siderolithic relics (triangles) at the bottom and rim of the structure. The sketch is not drawn to scale.

gression. This leaves only little time for the Eocene erosion to break through the Garschella Formation and to form the discussed structures.

The question therefore arises as to how these structures have originated and why they are so localised. It seems to be evident that the origin of the paleodolines cannot be attributed to the Eocene paleokarst alone. Other factors must be considered as well. It must be postulated that there was some kind of sedimentary or tectonic weakness zone in these places beforehand that allowed the Eocene erosion to break through the Garschella Formation much easier than it would have done otherwise.

Earlier studies (Masson 1980, Masson et al. 1980, Linder 2002) postulate a short Aptian phase of emersion and paleokarst of the Schrattenkalk Limestone before the deposition of the Garschella Formation. Probable traces of this earlier paleokarst can be seen throughout the Anzeindaz region and especially at La Corde, 200 meters to the east of the here described structure (ibid.). As the two paleokarsts seem to be superimposed, it is often difficult to tell one from another (Masson 1980). It is therefore possible, though rather unlikely that the paleodoline-like structures were already initiated in Aptian times and then re-excavated and deepened during the Eocene phase of continental erosion.

A much more probable possibility is the existence of a number of alpine faults related to the orogenic flexure of the alpine forebulge (Crampton \& Allen 1995, Sinclair et al. 1991) that could have provided the necessary weak zone for the Eocene erosion to attack. Indeed, Eocene synsedimentary faults (some of which are very large) are widely known throughout the Helvetic Realm (Menkveld-Gfeller 1993) as well as in the study area. The before-mentioned normal fault that cuts off the paleodoline of La Corde at its northeastern end (see 2. B) could be such an erosion-facilitating structure. Although there is no evidence for a pre- or synsedimentary activity of this fault and it is the only such fault at this place, alpine faults seem to be the most probable explanation for the origin of these structures.

\section{B) Spatial and temporal reconstruction}

From the descriptions of the paleodoline of La Corde and its sediment filling, its mapping and several sections (see figure 5) given herein and in Linder (2002), a reconstruction of the original structure can be established; it is given in figure 6. This allows for a temporal reconstruction of its evolution:

Lutetian to Bartonian: During the warm and humid, subtropical phase of continental exposure in the Early to Middle Eocene, synorogenic faulting most probably provided the weak zones alongside which the intense continental erosion could attack, eventually forming a paleodoline on a otherwise peneplained landscape. The sink-hole at its deepest point drained the eroded fine sediment fraction from the Garschella Formation. The bottom of the structure was already filled with the autochthonous rubble generated during its formation. Above this initial filling, land plants grew, forming a ferralitic paleosol with frequent Microcodium carpets. 
With the onset of the Eocene transgression at the turn from the Bartonian to the Priabonian, the area was now the intertidal zone of a beach. Here, paleosols were washed out, local gravels were reworked and the bottom of the structure was further filled with local rubble forming its transgressive base lag. On the surface of the Schrattenkalk Limestone at the rim of the structure, a small oyster reef grew. The top of the conglomerate was colonized by oysters and endolithic organisms such as Lithophaga bivalves and Cliona sponges.

In the Early Priabonian, with the continuing transgression over the surface of the mostly flat landscape, the paleodoline became a calm pool within a wide stretch of a shallow lagoon$\mathrm{al}$, subtropical sea. On top of the conglomerates, a small coral reef began to grow. In the pool, sandy limestone was deposited. A little while later on, and further to the west in the structure, the baffling effect of a stranded tree trunk may have temporarily generated a small muddy shallow or island with mangrove-like vegetation that harboured masses of gastropods, bivalves and other benthic animals. Thus, the situation during this stage can be compared to the recent environment at the coast of Florida.

In the Middle to Late Priabonian, with a continuing transgression, the pool was completely filled up. With the installation of open marine conditions and the deposition of the Pierredar Limestone over the completely filled structure, the early history of Eocene transgression was concluded.

\section{Acknowledgments}

This work was part of a diploma thesis at the University of Zürich under the supervision of Prof. H. Weissert and Dr. H.-P. Funk (both ETH Zürich). I would like to thank them, as well as Dr. U. Menkveld-Gfeller (NHM Bern) for their helpful advice and support. I also thank Prof. J. Geister (University of Bern), Prof. H. Masson (University of Lausanne), Profs. K. B. Föllmi and M. Burkhard and Haydon Mort (University of Neuchâtel) for their contributions. Last but not least, I'd like to thank Dres. D. Decrouez and M. Weidmann who reviewed this article.

\section{REFERENCES}

Badoux, H. 1973: Anzeinde et ses environs, aperçu géologique. Mém. Soc. Vaud. Sci. Nat. 15, 125-138.

Badoux, H., Gabus, J.-H. \& Mercanton, C.-H. 1990: Feuille Les Diablerets et notice explicative (2 ème édition), Atlas géol. de la Suisse au 1:25 000 . Comm. Géol. Suisse, 63 p.

BoussAC, J. 1912: Études stratigraphiques sur le Nummulitique alpin. Mém. Serv. Carte géol. France, 657 p.

BURKHARD, M. \& SOMMARUGA, A. 1998: Evolution of the Swiss Molasse basin: structural relations with the Alps and the Jura belt. In: MASCLE et al. (eds.): Cenozoic Foreland Basins of Western Europe. Geol. Soc. Spec. Pub. 134, 279-298.
Crampton, S.L. \& Allen, P.A. 1995: Recognition of forebulge unconformities associated with early stage foreland basin development: Example from the north Alpine foreland basin. Bull. Am. Assoc. Petrol. Geol. 79, 1495-1514.

Gradstein, F.M., OGG, J.G. \& Smith, A.G. (eds) 2004: Geologic Time Scale 2004. Cambridge Univ. Press, $500 \mathrm{p}$.

Herb, R. 1988: Eocaene Paläogeographie und Paläotektonik des Helvetikums. Eclogae geol. Helv. 81, 611-657.

LINDER, P. 2002: Die Entwicklung des helvetischen Ablagerungsraumes in der Morcles-Decke von Anzeindaz (VD) zwischen Kreide und Tertiär - Ausgewählte Aspekte zur Sedimentologie, Stratigraphie und Paläontologie. Unpublished diploma work, Inst. geol. Univ. Zürich., 144 p.

Lugeon, M. 1919: Sur le sidérolithique de La Cordaz (Alpes vaudoises). Bull. Soc. Vaud. Sci. Nat. 52, 109-110.

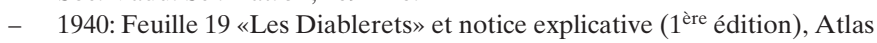
géol. de la Suisse au 1:25’000. Comm. Géol. Suisse, 52 p.

Lugeon, M. \& Argand, E. 1937: Notice explicative, Feuille 485 «Saxon-Morcles», Atlas géol. de la Suisse au 1:25’000. Comm. Géol. Suisse, 22 p.

Masson, H. 1980: Paléokarsts crétacés et tertiaires dans la nappe de Morcles. In: MAsson et al. (eds.): Compte rendu de l'excursion de la Société géologique Suisse du 1 au 3 octobre 1979: coupe Préalpes-HelvétiquePenninique en Suisse occidentale. Eclogae geol. Helv. 73, 331-349.

Masson, H., Herb, R. \& Steck, A. 1980: Helvetic Alps of Western Switzerland. With contributions by S. Ayrton, H. BAdoux, P. Bugnon, E. DoLIVO \& J. Gabus, (Excursion No 1). In: TRÜMPY, R. (ed.): Geology of Switzerland, a guide-book. Part B: Geological Excursions. Wepf \& Co. Publishers, Basel, New York, 109-153.

Menkveld-Gfeller, U. 1993: Stratigraphie und Paläogeographie des Eocaens der helvetischen Decken der Westschweiz (Diablerets- und Wildhorn-Decke). Unpublished PhD thesis, geol. Inst. Univ. Bern, 105 p.

- 1994: Die Wildstrubel-, die Hohgant- und die Sanetsch-Formation: Drei neue lithostratigraphische Einheiten des Eocaens der helvetischen Decken. Eclogae geol. Helv. 87, 789-809.

- 1995: Stratigraphie, Fazies und Palaeogeographie des Eocaens der helvetischen Decken der Westschweiz. Eclogae Geol. Helv. 88, 115-134.

Renevier, E. 1854: Seconde note sur la géologie des Alpes vaudoises. Bull. Soc. Vaud. Sci. Nat. 4, 204-218.

- 1890: Monographie géologique des Hautes-Alpes vaudoises et parties avoisinantes du Valais. Mat. carte géol. Suisse 16, 562 p.

RykKen, J. 1968: The nummulithic of the Nappe de Morcles. Mém. Soc. Vaud. Sci. Nat. 89, 193-232.

SinclaiR, H.D., CoAKLey, B.J., Allen, P.A. \& WatTs, A.B. 1991: Simulation of foreland basin stratigraphy using a diffusion model of mountain uplift and erosion: an example from the central Alps, Switzerland. Tectonics 10, 599-620.

Trümpy, R. (ed.) 1980: Geology of Switzerland - a guide-book. Wepf \& Co. Publishers, Basel, New York, 334 p.

Weidmann, M. 1984: Paléokarst éocène dans l'Autochtone chablaisien (VS et VD). Bull. Murithienne 102, 119-127.

Weidmann, M., Franzen, J. \& Berger J.-P. 1991: Sur l'âge des Couches à Cérithes ou Couches des Diablerets de l'Eocène alpine. Eclogae geol. Helv. 84, 893-919.

Wieland, B. 1976: Petrographie eocaener siderolithischer Gesteine des Helvetikums der Schweiz. Ihre Diagenese und schwache Metamorphose. Unpublished $\mathrm{PhD}$ thesis, geol. Inst. Univ. Bern, $118 \mathrm{p}$.

Manuscript received May 24, 2004

Revision accepted February 3, 2005 
